\title{
Activity pattern of bacteria in biodigester based on gas production and burning hour analyses
}

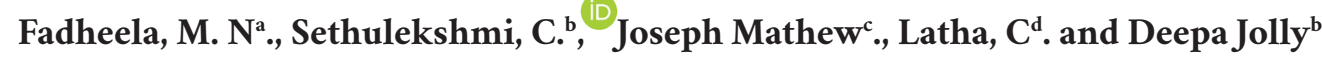

${ }^{a}$ Research Scholar, Department of Veterinary Public Health, College of Veterinary and Animal Sciences, Mannuthy, Kerala Veterinary and Animal Sciences University, India

${ }^{\mathrm{b}}$ Assistant Professor, Department of Veterinary Public Health, College of Veterinary and Animal Sciences, Mannuthy, Kerala Veterinary and Animal Sciences University, India

'Professor, Department of Livestock Production Management, College of Veterinary and Animal Sciences, Mannuthy, Thrissur, Kerala, India

${ }^{\mathrm{d} D e a n}$, College of Veterinary and Animal Sciences, Mannuthy, Kerala Veterinary and Animal Sciences University, India

Corresponding author: Sethulekshmi, C. | email: sethulekshmi@kvasu.ac.in

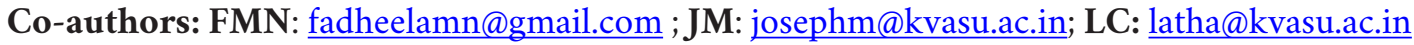

DJ: deepajolly@kvasu.ac.in

Received: 12-08-2020, Accepted: 21-09-2020, Published online: 18-10-2020

\section{Abstract}

Pollution around the world continues to grow and hence there is a growing interest in devising efficient and cost effective waste management. Biogas technology has in recent times viewed as a very good source of sustainable waste management. The present study was undertaken to investigate the role of different types of mesophilic, thermophilic and anaerobic bacteria in the bio digester responsible for biogas production. The activity pattern of bacteria in the bio digester based on gas production and the burning hour analyses of the biogas were also estimated in the study.

Six samples of slurry from two biodigesters; one installed at University livestock farm and other at buffalo farm in the College of Veterinary and Animal Sciences, Mannuthy were collected using a pump in to UV sterilised polythene bag and subjected to microbial analysis. The activity pattern of microorganisms in the biodigester at the buffalo farm was studied based on the gas production pattern (Sasse, 1988). When the mean total viable count were examined (Mortan, 2001) from top to bottom of biodigester it was observed that aerobic mesophilic counts decreased and anaerobic mesophilic counts increased towards bottom. While both aerobic and anaerobic thermophilic bacterial count increased towards the bottom of the biodigester. Methanogenic bacteria constituting the thermophilc organisms were found to be actively growing at the bottom of biodigester. The burning hour analysis of biogas from one of the biodigester (at the buffalo farm) was also carried out (Sasse, 1988). Burning hour analysis showed that a volume of $0.1074 \mathrm{~m}^{3}$ methane rich biogas could produce a blue flame for an hour. The study illustrates the importance of biogas technology, besides supplying energy and manure, provides an excellent opportunity for mitigation of greenhouse gas emission and reducing global warming through substituting firewood for cooking.

Keywords: biogas, biodigester, activity pattern, burning hour

\footnotetext{
doi: https://doi.org/10.51128/ffas.2020.A008 / How to cite this article: Fadheela, M. N., Sethulekshmi, C., Mathew, J., Latha, C. and Jolly, D., 2020. Activity pattern of bacteria in biodigester based on gas production and burning hour analyses. Journal of Food and Animal Sciences, 01(01): 44-47. Copyright: Fadheela et al. Open Access. This article is distributed under the terms of the Creative Commons Attribution 4.0 International License (http://creativecommons.org/licenses/by/4.0/), which permits unrestricted use, distribution, and reproduction in any medium, provided you give appropriate credit to the original author(s) and the source, provide a link to the Creative Commons license, and indicate if changes were made. The Creative Commons Public Domain Dedication waiver (http://creativecommons.org/publicdomain/zero/1.0/) applies to the data made available in this article, unless otherwise stated.
} 


\section{Introduction}

Pollution around the world continuous to grow and hence there is a growing interest in devising efficient and cost effective waste management system. The rapid growth of the population in the past decades has resulted in factors such as increased urban wastes and intensification of agriculture. The waste products of farms, such as animal manures, straw and other feed waste as well as wastes generated from slaughter houses are high in pathogenic microorganisms and therefore hazardous to human and animal health. (Irshad et al., 2015). Decontamination method to safeguard human and environmental health is necessary, particularly when dealing with food producing establishments. Anaerobic methanogenic fermentation is an attractive method for this purpose, as it converts the waste materials into useful products. Biogas technology has in recent times viewed as a very good source of sustainable waste -treatment, as it provides a renewable source of energy by converting organic waste into biogas and therefore reduces emissions that contribute to the green house effect.

The predominant component of flammable biogas is methane and carbondioxide with traces of other gases like $\mathrm{H} 2, \mathrm{NH} 3, \mathrm{CO} 2$ and water vapour (Irshad and Sharma, 2015). The odour control and clean burning properties of biogas process allow it to be used in the densest urban environment, making the largest cities into smaller bio-villages. The present study was undertaken to investigate the role of different types of mesophilic, thermophilic and anaerobic bacteria in the biodigester responsible for biogas production. The activity pattern of bacteria in the biodigester based on gas production and burning hour analyses of the biogas were also estimated in the study.

\section{Materials and methods}

In the present study three samples of slurry from each of two biodigesters, one installed at University livestock farm and other at buffalo farm of college of Veterinary and Animal Sciences, Mannuthy were collected and subjected to microbial analysis in order to study the role of different microorganism in the biogas plant. The activity pattern of microorganism in the biodigester (at the buffalo farm) was studied based on the gas production pattern. The burning hour analysis of biogas from one of the biodigesters (at the buffalo farm) was also carried out.
Three samples each from different depths (top, middle and bottom) from two different biodigesters were collected in UV sterilized polythene bags and were transported to the laboratory for processing. The samples were subjected to microbial analyses. Total Viable Count (TVC) of each sample was estimated by pour plate method (Mortan, 2001). The activity pattern of microorganisms in the biodigester at the buffalo farm was studied based on the gas production pattern (Sasse, 1988). The circumference of the gas collection chamber of one of the biodigester was measured and radius was calculated. The biodigester was then freshly charged with dung. The height of the gas collection chamber was measured at an interval of one hour and the measurements were taken for 24 hours. Using the measurements, volume of gas production at each time interval was calculated using the formula $V=\pi r^{2} h$.

The burning hour analysis was done in order to assess the flame producing capacity of the biogas from one of the biodigesters (at the buffalo farm). The initial height of the gas collection chamber was measured and volume was calculated using the formula $V=\pi r^{2} h$. The burner to which the gas lines are connected were turned off and the final height of the gas collection chamber was measured to calculate the final volume using the same formula. Thus the volume of gas capable of producing a flame for an hour was calculated (Sasse, 1988).

\section{Results}

\section{Total viable count of slurry samples}

The mean TVC of slurry samples from biodigester 1 and biodigester 2 were as shown in Table 1.

Evaluation of data was carried out by paired t-test using SPSS soft ware. Among the top, middle and bottom slurry samples the highest mean TVC counts were observed for the aerobic mesophiles in biodigester 1 and biodigester 2 . However the aerobic mesophiles were tend to decrease while the anaerobic mesophilic count was found to increase towards the bottom when the mean TVC counts in log $10 \mathrm{cfu} / \mathrm{ml}$ were observed from top to bottom of both digesters respectively. Both aerobic and anerobic thermophilic bacterial counts were found to increase towards the bottom of the biodigesters.

\section{Biogas production analysis}

The freshly charged biodigester at the buffalo farm was observed for gas production per hour from 8 am of day 1 to 8 am of day 2. The biogas production 
Table. 1: Mean TVC of slurry samples from biodigester 1 and biodigester 2

\begin{tabular}{|l|c|c|c|c|}
\hline \multirow{2}{*}{$\begin{array}{c}\text { Sample depth } \\
\text { Biodigester 1 }\end{array}$} & \multicolumn{4}{|c|}{ Overall Mean TVC +- S. E log 10 cfu/ml } \\
\cline { 2 - 5 } & $\begin{array}{c}\text { Aerobic } \\
\text { mesophile }\end{array}$ & $\begin{array}{c}\text { Aerobic } \\
\text { thermophile }\end{array}$ & $\begin{array}{c}\text { Anaerobic } \\
\text { mesophile }\end{array}$ & $\begin{array}{c}\text { Anaerobic } \\
\text { thermophile }\end{array}$ \\
\hline Top & $12.52 \pm 0.009^{\mathrm{a}}$ & $4.09 \pm 0.26^{\mathrm{a}}$ & $4.24 \pm 0.019^{\mathrm{a}}$ & $4.36 \pm 0.005^{\mathrm{a}}$ \\
\hline Middle & $12.41 \pm 0.00^{\mathrm{b}}$ & $4.51 \pm 0.010^{\mathrm{b}}$ & $4.35 \pm 0.014^{\mathrm{b}}$ & $4.64 \pm 0.006^{\mathrm{b}}$ \\
\hline Bottom & $12.08 \pm 0.002^{\mathrm{c}}$ & $4.68 \pm 0.006^{\mathrm{c}}$ & $4.74 \pm 0.006^{\mathrm{c}}$ & $4.80 \pm 0.003^{\mathrm{c}}$ \\
\hline Overall mean & $12.34 \pm 0.004$ & $4.43 \pm 0.014$ & $4.44 \pm 0.013$ & $4.60 \pm 0.004$ \\
\hline \multicolumn{1}{|c|}{$\begin{array}{l}\text { Sample depth } \\
\text { Biodigester 2 }\end{array}$} & & & & \\
\hline Top & $12.71 \pm 0.006^{\mathrm{a}}$ & $4.09 \pm 0.026^{\mathrm{a}}$ & $4.35 \pm 0.014^{\mathrm{a}}$ & $4.41 \pm 0.010^{\mathrm{a}}$ \\
\hline Middle & $5.97 \pm 2.11^{\mathrm{b}}$ & $4.42 \pm 0.012^{\mathrm{h}}$ & $4.00 \pm 0.066^{\mathrm{b}}$ & $4.71 \pm 0.006^{\mathrm{b}}$ \\
\hline Bottom & $7.35 \pm 2.23^{\mathrm{c}}$ & $4.67 \pm 0.007^{\mathrm{c}}$ & $4.71 \pm 0.007^{\mathrm{c}}$ & $4.75 \pm 0.005^{\mathrm{c}}$ \\
\hline Overall mean & $8.67 \pm 1.45$ & $4.39 \pm 0.015$ & $4.36 \pm 0.029$ & $4.62 \pm 0.007$ \\
\hline
\end{tabular}

Figures bearing same superscript do not differ significantly

at regular intervals was recorded. The volume of gas production was found to increase significantly during the initial period of observation and then, later on the volume of gas production was observed to be stable, with a gradual increase during the end of observation period. The highest volume of gas produced was $1.576 \mathrm{~m}^{3}$ at the $24^{\text {th }}$ hour of observation, while the lowest volume of gas produced was $1.57 \mathrm{~m}^{3}$ at the first hour of observation period. A uniform volume of gas production was observed at 4 to $8 \mathrm{pm}$ of day 1 (2.14 $\left.\mathrm{m}^{3}\right) 10$ to $11 \mathrm{pm}$ of day $1\left(2.30 \mathrm{~m}^{3}\right), 2$ to 4 am of the day $2\left(2.43 \mathrm{~m}^{3}\right)$ and at 5 to $7 \mathrm{am}$ of day $2\left(2.50 \mathrm{~m}^{3}\right)$.

\section{Burning hour analysis}

The burning hour analysis from the biodigester at the buffalo farm was carried out to estimate the capacity of biogas to produce the flame. Analysis was conducted by measuring the initial and final volume using the formula $V=\pi r^{2} h$. From the analysis carried out, it was observed that a volume of $0.1074 \mathrm{~m}^{3}$ of biogas produced from the biodigester was capable to produce a blue flame for an hour.

\section{Discussion}

In the present study both aerobic and anaerobic thermophilic counts were found to increase towards the bottom of the digesters. The earlier studies (Jones and Matthews, 1974) reported that out of 187 samples of slurry from cattle TVC per sample of slurry ranged widely and the highest count of aerobic mesophiles was about $9.0 \log _{10} \mathrm{cfu} / \mathrm{ml}$ which was three log lesser than the aerobic mesophilic count from the digester 1 and one log greater than the aerobic mesophilic count obtained from digester 2 in the present study. The variation in mean TVC counts obtained in the current study from other previous researches may be due to difference in source of biodigester feed (cattle manure, pig manure and slaughter house waste), method of sampling (depth sampling, random sampling) and instances of sampling (at the time of charging, before digestion, after digestion).

The activity pattern of microorganism in the biogas plant was estimated based on the volume of gas production in the biodigester. When the volume of gas production was evaluated for 24 hours, it was found that the volume of gas production increased significantly during the initial period of observation, followed by a short declination and then a stable production of gas with gradual increase of gas production towards the end of the observation period. A similar pattern of gas production was reported by Thy et al. (2003) who observed that the gas was found to increase gradually during adaptation period before reaching a plateau period. The biogas production pattern corresponds to the activity pattern of microorganism in the biogas plant, in particular the methanogenic bacteria. Methanogens which are thermophiles are responsible for production of major component of biogas, methane. A sharp increase in gas production in the initial stage must be probably due to aclimitization of biogas producing microorganism after hydrolysis of waste in the beginning by hydrolyzing organisms: while declination in gas production was deduced to be due to decline in action of biogas producing organism as they were replaced by organisms that tend to utilize some of the products of their action.

The burning hour analysis was carried out and 
the capacity of the biogas to produce the flame was estimated as $0.1074 \mathrm{~m}^{3} / \mathrm{h}$. About $0.04833 \mathrm{~m}^{3}$ of volume must be methane according to report and methane content of 45 percent is required to make biogas combustible and a lesser content does not produce flame (Anonymous, 2003).

\section{Conclusion}

The result suggests that most of the methanogenic bacteria responsible for methane production, the main content of the biogas resided and actively grew at the bottom of the biodigester. The analysis of biogas production was carried out to evaluate the activity pattern of bacteria. A higher gas production was observed only after few hours of observation indicating that methanogenic bacteria required a specific adaptation period and increased temperature for its optimal activity. The capacity of the biogas produced was evaluated by conducting the burning hour analysis and it was found that a volume of $0.1074 \mathrm{~m}^{3}$ mehane rich biogas could continuosly produce a blue flame for an hour.

Biogas is a sustainable substitute for propane, kerosene and firewood that many rural families in developing countries use for their domestic energy needs. In addition to providing fuel, these systems offer an environmental friendly way of treating energy waste. In industrialized countries biogas almost always replaces existing energy sources like electricity, diesel or other gases. Thus the results obtained suggest that, biogas with excellent flame producing capacity can provide a better alternative for cooking gas and they can be produced easily from cheap sources like cattle manure and agricultural waste.

\section{Authorship contribution statement}

Fadheela, M. N: Conceptualization, Methodology, Software, Validation, Formal analysis, Investigation, Writing - original draft, Writing - review \& editing, Visualization, Supervision, Project administration, Funding acquisition. Sethulekshmi, C: Conceptualization, Methodology, Writing - original draft, Writing - review \& editing. Joseph Mathew: Conceptualization, Software, Data curation, editing. Latha, $C$ and Deepa Jolly: Conceptualization, Methodology \& editing.

\section{Acknowledgment}

The authors are thankful to the Dean, College of Veterinary and Animal Sciences, Mannuthy and Kerala Veterinary and Animal Sciences University for providing necessary facilities to carry out this work

\section{Funding}

None.

\section{Declaration of Competing Interest}

All authors declare that there exist no commercial or financial relationships that could, in any way, lead to a potential conflict of interest.

\section{Reference}

Anonymous. 2003. Waste digester design. University of Florida Civil Engineering. Retrieved from the world wide web: http: file//A:/Design. Tutor. htm.2003

Irshad, A., Talukder, S., Selvakumar, K. 2015. Current Practices and Emerging Trends in Abattoir Effluent Treatment in India: A Review. Int. J. Livest. Res. 5(2): 13-31. doi: 10.5455/ ijlr.20150225043513

Irshad, A. and Sharma,B. D. 2015. Slaughter House by-Product Utilization for Sustainable Meat Industry: A Review. Journal of Animal Production Advances. 5(6):1. Doi: 10.5455/ japa.20150626043918

Jones, P. W. and Matthews, P.R.J. 1974. Examination of slurry from cattle for pathogenic bacteria. J. Hyg. 57-64

Mortan, D.R. 2001. Aerobic plate count. In: Downes, F. P. and Ito, K. (eds) Compendium of methods for the microbial examination of foods. ( ${ }^{\text {th }} \mathrm{Ed}$.). American Journal of Public Health ${ }^{\circledR}, 800$ I Street NW, DC.

Sasse, L. 1988. Biogas plants. (2 $2^{\text {nd }}$ Ed). A publication of the Duetsches zentrum fur wicklungs technologies- GATE. Vieweg and Sohn, Germany, 5-48 p

Thy, S., Preston, T. R. and Ly, J. 2003. Effect of retention time on gas production and fertilizer value of biodigester effluent. Livest. Res.Rural Dev. 15(7) 